\title{
EFFECT OF 30 MINUTES WALKING ON BLOOD PRESSURE OF ELDERLY IN PACCERAKKANG DISTRICT OF MAKASSAR
}

\author{
Andi Nurfadilah Rezky ${ }^{1}$, Nurmiyanti Nur ${ }^{2}$, Rismawati Samad ${ }^{3}$, \\ Arnis Puspitha $\mathbf{R}^{4}$ \\ 1,2, 3,4 Fakultas Keperawatan Universitas Hasanuddin, Makassar \\ email : arnis.puspitha@yahoo.com
}

\begin{abstract}
Introduction: Sports activity affects a person's fitness level. Sports activities in the form of aerobic exercise, resistance or resistance training and flexibility exercises can improve your fitness. The exercise was done with medium intensity 3 times per week and 30 minutes duration. The importance of one's body fitness should get more attention. Especially in improving the quality of physical condition capabilities such as cardiovascular endurance, muscle strength and endurance, body shape. In this case a person can perform maximum exercise on the physical condition. This study aims to find out how the effect of walking 30 minutes to decrease blood pressure in elderly in working area of Health Center of Paccerakkang Kota Makassar. Method: This research is Quasy Experiment with Pre and Post Test Without Control design. The sample of research is 30 respondents. The research instrument is a tool to check uric acid levels and blood pressure measuring devices. Result: Based on hypothesis test which have been done, hence obtained conclusion that walking 30 min influence significantly to pressure drop blood. There's a differences of mean value of blood pressure before exercise where mean value of blood pressure before exercise was higher $(3,40 \mathrm{mmHg})$ compere to after exercise $(2,47 \mathrm{mmHg})$. From the test it was found that there is an effect of pre test to post test p-value 0.000 while the significance level $a=0.05$. Conclution: It can be concluded from this study that walking exercise has significant effect on decreasing blood pressure. By knowing the influence of elderly gymnastics on the decrease of blood pressure in elderly with hypertension, nurses are expected to give and suggest non-pharmacological intervention and walk 3 times a week with 30 minutes duration in minimizing risk of complication of hypertension.
\end{abstract}

Keywords: Footwear, blood pressure, elderly

\section{PENDAHULUAN}

Lanjut usia merupakan tahap terakhir dari siklus hidup manusia, yang pastinya akan mengalami perubahan baik fisik maupun mental. Penuaan penduduk di Indonesia berkembang pesat. Saat ini penduduk lanjut usia di Indonesia telah mengalami peningkatan dari sebelumnya yaitu berjumlah sekitar 24 juta dan tahun 2020 diperkirakan akan meningkat sekitar 30-40 juta jiwa. (Komnas lansia, 2011 seperti di kutip dalam Kartikasari dan Handayani, 2012).

Salah satu PTM (Penyakit Tidak Menular) yang menjadi penyebab kematian paling umum adalah hipertensi. Definisi Hipertensi atau tekanan darah tinggi adalah peningkatan tekanan darah sistolik lebih dari $140 \mathrm{mmHg}$ dan tekanan darah diastolik lebih dari $90 \mathrm{mmHg}$ pada dua kali pengukuran dengan selang waktu lima menit dalam keadaan cukup istirahat/tenang. Peningkatan tekanan darah yang berlangsung dalam jangka waktu lama (persisten) dapat menimbulkan kerusakan pada ginjal (gagal ginjal), jantung (penyakit jantung koroner) dan otak (menyebabkan stroke) bila tidak dideteksi secara dini dan mendapat pengobatan yang memadai (Pusat Data dan Informasi Kemenkes RI, 2014). Menurut data dari WHO (2015) dalam 
Singh, Shankar, \& Singh (2017) bahwa prevalensi laki-laki dan perempuan penderita hipertensi di India adalah masing-masing $24,2 \%$ dan 22,7\%. Penyakit hipertensi termasuk penyakit dengan jumlah kasus terbanyak pada pasien rawat jalan yaitu 80.615 kasus. Hipertensi merupakan penyakit yang persentase kematiannya terhadap seluruh pasien mati dirawat inap yang meningkat (Pusat Data dan Informasi, 2012). Berdasarkan data Riskesdas (2010) dalam Abikusno, Turana, \& Santika (2013) prevalensi hipertensi di Indonesia adalah sebesar 26,5\% dan cakupan diagnosis hipertensi oleh tenaga kesehatan mencapai 36,8\%.

Aktivitas olahraga berpengaruh terhadap tingkat kebugaran seseorang. Aktivitas olahraga dalam bentuk latihan aerobik, latihan resisten atau ketahanan dan latihan fleksibilitas dapat meningkatkan kebugaran tubuh. Latihan dilakukan dengan intensitas sedang frekuensi 3 kali perminggu dan durasi 30 menit. Pentingnya kebugaran tubuh seseorang harus mendapatkan perhatian yang lebih. Khususnya dalam peningkatan kualitas kemampuan kondisi fisik seperti daya tahan kardiovaskuler, kekuatan dan daya tahan otot, kelentukan tubuh. Dalam hal ini seseorang dapat melakukan latihan yang maksimal terhadap kondisi fisik tersebut (Prativi, Soegianto, Sutardji, 2013).

Latihan jalan kaki memang sangat ringan dan sederhana, tetapi jika dilakukan dengan terprogram, sistematis dan terstruktur akan mendapat hasil positif terhadap tingkat kebugaran dan kesehatan. Artinya tidak jauh berbeda pengaruhnya dengan olahraga aerobik lainnya. Dalam pelaksanaan penelitian ini, latihan jalan kaki yang ditujukan untuk membantu menurunkan tekanan darah sistolik dan diastolik pada penderita hipertensi adalah dengan intensitas latihan 30 menit. Sadoso (1996) dalam Prativi, et al, (2013) mengatakan bahwa,"takaran lamanya latihan untuk olahraga kesehatan antara 2030 menit dalam training zone. Latihanlatihan tidak akan efisien atau kurang membuahkan hasil kalau kurang dari takaran tersebut.

\section{METODE}

Penelitian ini telah disetujui oleh Komisi Etik Fakultas Keperawatan Universitas Hasanuddin yang dilakukan sejak Agustus 2017 di Puskemas Paccerakkang, Kecamatan Biringkanayya, Makassar. Desain dalam penelitian ini adalah Quasy Eksperiment dengan rancangan Pre and Post Test Without Control yaitu penelitian ini dilakukan dengan cara satu kelompok tanpa pembanding, kemudian membandingkan sebelum dan sesudah intervensi. Kriteria inkusi dalam penelitian ini yaitu (1) lansia dalam keadaan sehat, mampu berjalan sendiri sendiri tanpa bantuan orang lain/alat, misalnya tongkat/walker; (2) Lansia dengan tekanan darah ( $\geq 150 / 90 \mathrm{mmHg}$ ); (3) Lansia yang bersedia sebagai partisipan.

\section{Intervensi Jalan Kaki 30 menit}

Berjalan kaki adalah serangkaian langkah lurus kedepan secara terusmenerus dengan kaki dilangkahkan satu persatu ke depan dan bergerak seiring dengan langkah. Dengan berjalan kaki, pada setiap tingkat atau kecepatan, 2 atau 3 kali dalam 1 Minggu paling tidak 20 menit akan meningkatkan ketahanan pembuluh jantung. Dengan meningkatkan ketahamnan jantung dan paru-paru akan meningkatkan kemampuan tidak hanya berlatih lebih lama dan lebih kuat, tetapi juga untuk melaksanakan tugas-tugas harian tanpa merasa lelah. 


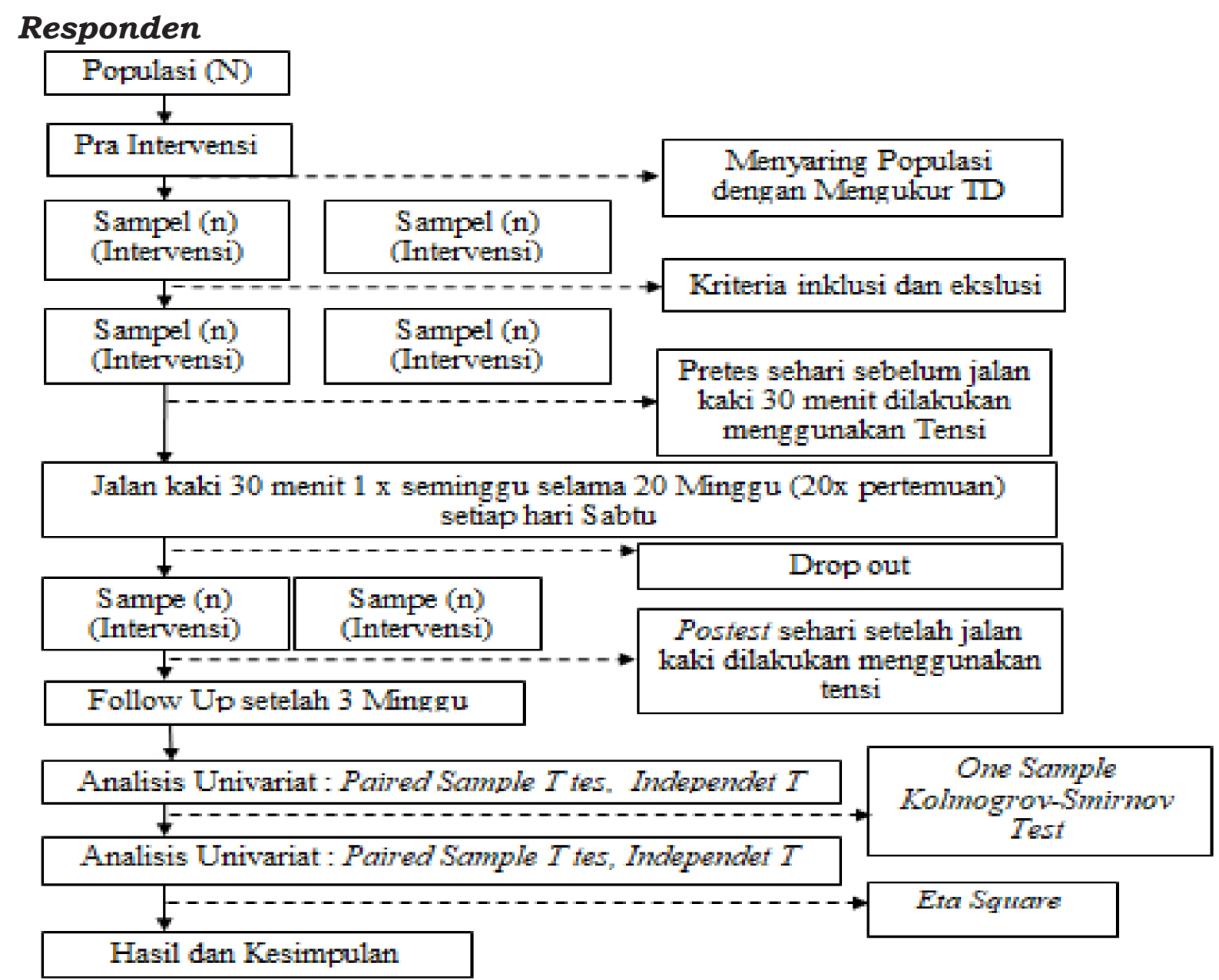

Gambar 1. Flow chart responden penelitian

\section{HASIL}

Karakteristik Responden

Umur

Jenis Kelamin

Pendidikan

Pekerjaan
$<45-60$

$>60$

Laki-laki

Perempuan

Tidak sekolah

SD

SMP

SMA

Perguruan Tinggi

Tidak Bekerja

Wiraswasta
Frekuensi (f) Persentase (\%)

27

90,0

10,0

$\begin{array}{ll}3 & 10,0 \\ 27 & 90,0\end{array}$

620,0

$7 \quad 23,3$

$7 \quad 23,3$

930,0

$1 \quad 3,3$

$7 \quad 23,3$

$11 \quad 36,7$

Tabel. 1. Karakteristik Responden $(n=30)$

Berdasarkan tabel 4.1 diatas didapat bahwa dari 30 responden dalam penelitian ini terdapat 27 orang pasien berusia $<45-60$ tahun, dan 3 orang responden berusia $>60$ tahun. Jenis kelamin yang mayoritas adalah perempuan sebanyak 27 orang $(90,0 \%)$.
Responden mayoritas pendidikan SMA 9 orang $(30,0 \%)$, dilihat dari pekerjaan responden, pekerjaan mayoritas responden adalah IRT 12 orang (40,0\%).

Dari hasil pemeriksaan tekanan darah terdapat bahwa rata-rata frekuensi nilai tekanan darah sebelum 
dilakukan jalan kaki adalah minimum yaitu 140 (3) dan maksimal 180 (5) dan setelah dilakukan jalan kaki adalah minimum yaitu 120 (2) dan maksimal 150 (3).

Pengujian Normalitas dapat dilakukan melalui uji Shapiro-Wilk. Uji Shapiro-Wilk merupakan salah satu uji yang digunakan untuk mengetahui apakah data berdistribusi normal atau tidak.

\begin{tabular}{cccccc}
\hline & n & Minimum & Maximum & Mean & $\begin{array}{c}\text { Std. } \\
\text { Deviation }\end{array}$ \\
\hline $\begin{array}{c}\text { Tekanan } \\
\text { Darah_Pre }\end{array}$ & 30 & 3 & 5 & 3,40 & .621 \\
$\begin{array}{c}\text { Tekanan } \\
\text { Darah_Post } \\
\begin{array}{c}\text { Valid N } \\
\text { (listwise) }\end{array}\end{array}$ & 30 & 2 & 3 & 2,47 & .507 \\
\hline
\end{tabular}

Tabel 2. Distribusi Frekuensi Nilai Tekanan Darah

\begin{tabular}{lcccccc}
\hline & \multicolumn{3}{c}{ Kolmogorov-Smirnova } & \multicolumn{3}{c}{ Shapiro-Wilk } \\
Pretest_TD & Statistic & Df & Sig. & Statistic & df & Sig. \\
Posttest_TD & .407 & 30 & .000 & .656 & 30 & $\mathbf{. 0 0 0}$ \\
& .354 & 30 & .000 & .637 & 30 & $\mathbf{. 0 0 0}$ \\
\hline
\end{tabular}

Tabel 3. Hasil Uji Normalitas Dengan Uji Shapiro-Wilk.

Hasil uji statistik dengan uji Wilcoxon Signed Ranks Test Hasil Pengukuran Tekanan Darah Sebelum dan sesudah jalan kaki.

$\begin{array}{lc} & \text { Posttest_TD - Pretest_TD } \\ Z & -4.772^{\mathrm{b}} \\ \text { Sig. (2-tailed) } & \mathbf{0 0 0}\end{array}$

Asymp. Sig. (2-tailed) .000

Tabe1 4. Hasil Uji Statistik Dengan uji Wilcoxon Signed Ranks Test Hasil Pengukuran Tekanan Darah Sebelum dan sesudah jalan kaki.

\section{PEMBAHASAN}

Berdasarkan hasil penelitian di Wilayah Kerja Puskesmas Paccerakkang Makassar yang mulai dilakukan pada September 2017 sampai Oktober 2017 yang melakukan pengukuran nilai tekanan darah sebelum dan setelah berjalan kaki 30 menit rata-rata tekanan darah lansia mengalami penurunan yang signifikan.

Aktivitas olahraga berpengaruh terhadap tingkat kebugaran seseorang. Aktivitas olahraga dalam bentuk latihan aerobik, latihan resisten atau ketahanan dan latihan fleksibilitas dapat meningkatkan kebugaran tubuh. Latihan dilakukan dengan intensitas sedang frekuensi 3 kali perminggu dan durasi 30 menit. Pentingnya kebugaran tubuh seseorang harus mendapatkan perhatian yang lebih. Khususnya dalam peningkatan kualitas kemampuan kondisi fisik seperti daya tahan kardiovaskuler, kekuatan dan daya tahan otot, kelentukan tubuh. Dalam hal ini seseorang dapat melakukan 
latihan yang maksimal terhadap kondisi fisik tersebut (Prativi, et. al 2013).

Latihan jalan kaki memang sangat ringan dan sederhana, tetapi jika dilakukan dengan terprogram, sistematis dan terstruktur akan mendapat hasil positif terhadap tingkat kebugaran dan kesehatan. Artinya tidak jauh berbeda pengaruhnya dengan olahraga aerobik lainnya. Dalam pelaksanaan penelitian ini, latihan jalan kaki yang ditujukan untuk membantu menurunkan tekanan darah sistolik dan diastolik pada penderita hipertensi adalah dengan intensitas latihan 30 menit. Sadoso (1996) dalam Prativi, et al, (2013) mengatakan bahwa, takaran lamanya latihan untuk olahraga kesehatan antara 20-30 menit dalam training zone. Latihanlatihan tidak akan efisien atau kurang membuahkan hasil kalau kurang dari takaran tersebut.

Berdasarkan hasil Uji Sample Berpasangan didapatkan rata-rata nilai tekanan darah setelah dilakukan intervensi jalan kaki 30 menit adalah $120 \mathrm{mmHg}$, yang berarti bahwa tekanan darah responden normal. Hal ini dapat terjadi karena jalan kaki dapat memperbaiki peredaran darah yang terganggu dan memperkuat otot-otot pada lansia. Jalan kaki yang dilakukan peneliti di Wilayah Kerja Puskesmas Paccerakkang Makassar tahun 2017 sebanyak 30 responden, didapatkan 30 responden $(100 \%)$ yang mengalami penurunan tekanan darah. Olahraga dapat meningkatkan kekuatan otot, massa otot, perfusi otot, dan kecepatan konduksi saraf ke otot (Rachmah, 2013 dalam Pribadi, 2015). Pada prinsipnya, olah raga untuk lansia harus dimulai pada kadar aktivitas yang sangat ringan kemudian secara bertahap meningkat sampai pada kadar aktivitas sedang. Untuk mendapatkan hasil maksimal, olahraga lansia sebaiknya terdiri dari tiga komponen olahraga, yaitu latihan aerobik, latihan kekuatan dan latihan keseimbangan serta kelenturan. Latihan aerobik sangat erat kaitannya dengan kebugaran paru jantung, dimana jantung merupakan salah satu organ tubuh yang sangat penting dimiliki oleh manusia, jika jantung kita kuat maka jantung akan memompa darah keseluruh tubuh dengan kuat pula, sehingga aliran darah ke seluruh tubuh menjadi lancar. Maka dari pada itu pentingnya latihan aerobik untuk kebugaran paru jantung bagi lansia (Pribadi, 2015).

Berdasarkan tabel dapat dilihat bahwa hasil pengukuran awal tekanan darah semuanya tinggi yaitu mulai dari $140 \mathrm{mmHg}$ sampai $180 \mathrm{mmHg}$ dengan nilai mean 3,40 mmHg. Kebugaran jasmani juga sangat diperlukan untuk mencegah atau menunda penyakitpenyakit degeneratif dan penyakit kelainan metabolisme. Perlu adanya upaya-upaya baik besifat perawatan, pengobatan, pola hidup sehat dan juga upaya lain, seperti jalan kaki 30 menit untuk mempertahankan kesehatan lansia tersebut.

Setelah diberikan intervensi latihan jalan kaki 30 menit pada responden, didapatkan bahwa semua responden mengalami penurunan tekanan darah dengan nilai mean 2,47 $\mathrm{mmHg}$. Data analisa menyimpulkan ada pengaruh latihan jalan kaki 30 menit terhadap tekanan darah pada lansia penderita hipertensi. Menurut Surbakti (2014) dari kajian di atas bahwa berjalan kaki mempengaruhi kebugaran diantaranya berjalan kaki dapat membantu menurunkan lemak dan memperkuat otot, dengan berjalan kaki, pada setiap tingkat atau kecepatan, 2 atau 3 kali dalam 1 minggu paling tidak 20 menit akan meningkatkan ketahanan pembuluh jantung. Dengan meningkatkan ketahamnan jantung dan paru-paru akan meningkatkan kemampuan tidak hanya berlatih lebih lama dan lebih kuat, tetapi juga untuk melaksanakan tugas-tugas harian tanpa merasa lelah.

Latihan olahraga secara teratur akan dapat menurunkan tekanan darah. Jenis olahraga yang efektif menurunkan tekanan darah adalah 
olahraga dengan intensitas sedang. Frekuensi latihannya 3-5 kali seminggu, dengan lama latihan 20-60 menit sekali latihan (Syatria, 2006).

Berdasarkan hasil uji statistik diketahui bahwa nilai signifikan untuk pasangan variabel Pretest_TD-Posttest_ TD adalah sebesar 0.000 ini dilakukan dengan membandingkan antara nilai signifikan ( $p$-value) uji Wilcoxon Signed Ranks dan nilai a (alpha). H_0 diterima jika nilai $p$-value $\geq a$, sebaliknya H_O ditolak jika nilai p-value $<\mathrm{a}$. Berdasarkan perhitungan yang telah dilakukan, diperoleh $\mathrm{p}$-value untuk pasangan variabel pre test-posttest untuk tekanan darah adalah sebesar 0.000 sedangkan taraf signifikansi $\mathrm{a}=0.05$, Karena $\mathrm{p}$-value $=0.000<\mathrm{a}=0.05$, maka diputuskan bahwa H_0 ditolak. Dimana semua sampel berjumlah 30 responden yang melakukan jalan kaki mengalami penurunan tekanan darah. Dari hasil tersebut dapat diperoleh informasi bahwa responden yang diberi perlakuan jalan kaki akan mengalami penurunan tekanan daran dalam tubuh. Jalan kaki sangat penting untuk para lanjut usia untuk menjaga kesehatan tubuh mereka. Hasil identifikasi tekanan darah setelah dilakukan jalan kaki di dapatkan ratarata tekanan darah sistole 127,50 $\mathrm{mmHg}$ dan rata-rata tekanan darah diastole 78,75 mmHg. Didapatkan penurunan rata-rata tekanan darah sistolik 21,67 $\mathrm{mmHg}$ dan penurunan tekanan darah diastolik $12,50 \mathrm{mmHg}$. Pemberian jalan kaki berpengaruh secara signifikan terhadap tekanan darah. sistolik pada lansia dengan hipertensi yaitu nilai $\mathrm{p}(0,000)<0,05$ dan tekanan darah diastolik pada lansia dengan hipertensi yaitu $\mathrm{p}(0,000)$ $<0,05$.

\section{KESIMPULAN DAN SARAN}

Setelah dilakukan penelitian mengenai pengaruh jalan kaki terhadap penurunan tekanan darah pada di Wilayah kerja Puskesmas Paccerakkang Makassar, maka dapat disimpulkan bahwa tekanan darah responden sebelum dilakukan jalan kaki mempunyai nilai mean 3,40 $\mathrm{mmHg}$ dan susudah dilakukan jalan kaki mempunyai nalai mean 2,47 mmHg. Berdasarkan pengujian hipotesis yang telah dilakukan, maka diperoleh kesimpulan bahwa jalan kaki berpengaruh secara signifikan terhadap penurunan tekanan darah. Dengan mengetahui pengaruh jalan kaki terhadap penurunan tekanan darah pada lansia dengan hipertensi maka perawat diharapkan dapat memberikan dan menyarankan intervensi non farmakologis latihan nafas dan jalan kaki sebanyak 3 kali seminggu dalam meminimalkan risiko terjadinya komplikasi hipertensi.

\section{UCAPAN TERIMA KASIH}

Penelitian ini didukung oleh hibah penelitian mahasiswa Fakultas Kedokteran Universitas Hasanuddin tahun 2017.

\section{DAFTAR PUSTAKA}

Abikusno, A. D., Turana, D. Y., \& Santika, D. A. (2013). Gambaran Lanjut Usia di Indonesia. Jakarta: Kepala Pusat Dan Informasi Kementrian Kesehatan RI.

Kartikasari, D \& Handayani, F. (2012). Pemenuhan Kebutuhan Dasar Manusia Pada Lansia Demensia Oleh Keluarga. Jurnal Nursing Studies.

Prativi, Soegianto, Sutardji. (2013). Pengaruh Aktivitas Olahraga Terhadap Kebugaran Jasmani. Semarang: Conservation University

Pribadi, A. (2015). Pelatihan aerobik untuk kebugaran paru jantung bagi lansia. 11(5), 64-76.

Pusat Data dan Informasi. (2012). Data dan Informasi Kesehatan Penyakit Tidak Menular. Kementerian Kesehatan RI, p. Volume 2. https://doi.org/2088-270X

Pusat Data dan Informasi Kemenkes RI. (2014). Pusdatin Hipertensi. In Kemenkes RI. https://doi. org/10.1177/109019817400200403

RI, K. K. (2011 dan 2012). Pusat pembiayaan dan jaminan kesehatan .

Situmorang Paskah R. (2015). Faktor - Faktor Yang Berhubungan Dengan Kejadian Hipertensi Pada Penderita Rawat Inap Di Rumah Sakit Umum Sari Mutiara Medan Tahun 2014 Vol 1 No 1. Medan: Jurnal Ilmiah Keperawatan.

Singh, S., Shankar, R., \& Singh, G. P. (2017). Prevalence and Associated Risk Factors 
Indonesian Contemporary Nursing Journal, 3(2), 36-42

of Hypertension: A Cross-Sectional Study in Urban Varanasi. International Journal of Hypertension, 2017. https://doi. org/10.1155/2017/5491838

Surbakti, Sabar. (2014). Pengaruh Latihan Jalan Kaki 30 Menit Terhadap Penurunan Tekanan Darah Pada Pasien Penderita Hipertendi Di Rumah Sakit Umum
Kabanjahe Vol. 20 Nomor 77. Kabanjahe: Pengabdian Kepada Masyarakat

Syatria, A. (2006). Pengaruh Olahraga Terprogram Terhadap Tekanan Darah.

Tamher \& Noorkasiani. (2009). Kesehatan Usia Lanjut Dengan Pendekatan Asuhan Keperawatan. Jakarta: Salemba Medika 